\title{
PENGARUH WAKTU PENAHANAN TERHADAP SIFAT FISIS DAN MEKANIS PADA PROSES PENGKARBONAN PADAT BAJA MILD STEEL
}

\author{
Pramuko I. Purboputro \\ Teknik Mesin Universitas Muhammadiyah Surakarta \\ Jl.A. Yani Tromol Pos 1 Pabelan Kartasura
}

\begin{abstract}
ABSTRAK
Penelitian ini bertujuan untuk mengetahui pengaruh dari waktu penahanan terhadap perubahan sifat fisis dan mekanis pada proses pengarbonan baja mild steel. Temperatur yang digunakan selama proses pengarbonan berlangsung adalah $925^{\circ} \mathrm{C}$ dengan vareasi waktu tahan masing-masing 3 jam; 4 jam; 7 jam; 8 jam. Dalam proses pengarbonan sumber karbon didapat dari arang cangkang kelapa yang telah dibuat serbuk halus dan dicampur dengan $\mathrm{Na}_{2} \mathrm{CO}_{3}$ ( soda abu ) sebagai katalisnya. Kandungan karbon material dasarnya adalah 0,19\%C. Pengujian yang dilakukan adalah pengujian struktur mikro, pengujian kekerasan, pengujian kedalaman difusi dan pengujian komposisi kimia .Pengujian kekerasan yang telah dilakukan terhadap material pengarbonan menghasilkan distribusi kekerasan dari permukaan menuju inti, untuk masing-masing waktu penahanan yang berbeda. Untuk waktu penahanan 3 jam mulai $\mathrm{HVN} 735,7 \mathrm{Kg} / \mathrm{mm}^{2}$ sampai 440,9 $\mathrm{Kg} / \mathrm{mm}^{2}$ menuju inti ; 4 jam mulai $\mathrm{HVN} 762,9 \mathrm{Kg} / \mathrm{mm}^{2}$ sampai 462,8 $\mathrm{Kg} / \mathrm{mm}^{2}$ menuju inti ; 7 jam mulai $\mathrm{HVN} 781,9 \mathrm{Kg} / \mathrm{mm}^{2}$ sampai $478,4 \mathrm{Kg} / \mathrm{mm}^{2}$ menuju inti ; 8 jam mulai $H V N$ 801,5 Kg/mm² sampai 479,3 Kg/mm² menuju inti. Untuk pengujian kedalaman difusi didapat suatu persamaan $Y=0,0046 X^{2}+$ 0,0226 X +0,0013 dimana persamaaan tersebut menunjukkan kenaikan difusi karbon kedalam material pengujian. Sedangkan dalam pengujian komposisi kimia didapatkan kenaikan kandungan unsur karbon untuk masing-masing waktu penahanan. Untuk waktu penahanan 3 jam kandungan unsur karbon 0,259 \% ; 4 jam kandungan unsur karbon 0,352 \%; 7 jam kandungan unsur karbon 0,505 \% ; 8 jam kandungan unsur karbon 0,808\%.
\end{abstract}

Kata kunci : Pengkarbonan Padat, Difusi, Katalis, Waktu tahan

\section{PENDAHULUAN}

Pemakaian logam ferrous baik baja maupun besi cor dengan karakteristik dan sifat yang berbeda membutuhkan adanya suatu penanganan yang tepat sehingga implementasi dari penggunaan logam tersebut dapat sesuai dengan kebutuhan yang ada, khususnya baja. Penggunaan baja karbon rendah banyak digunakan lebih disebabkan karena baja karbon rendah memiliki keuletan tinggi dan mudah dimachining, tetapi kekerasannya rendah dan tidak tahan aus. Baja ini tidak dapat dikeraskan dengan cara konvensional karena kadar karbonnya yang rendah, sehingga dilakukan proses Carburising. Proses Carburising sendiri didefinisikan sebagai suatu proses penambahan kan- 
dungan unsur karbon (C) pada permukaan baja. Proses Carburising yang tepat akan menambah kekerasan permukaan sedang pada bagian inti tetap liat (ductile). Selain dari pada itu ada hal yang perlu diperhatikan sebelum memulai proses pengarbonan (Carburising), yaitu komposi kimia khususnya perubahan unsur karbon (C) akan dapat mengakibatkan perubahan sifatsifat mekanik baja tersebut.

\section{TINJAUAN PUSTAKA}

\section{Pengertian Baja Karbon}

Baja merupakan paduan yang terdiri dari unsur utama besi (Fe) dan karbon (C), serta unsur-unsur lain, seperti : $\mathrm{Mn}, \mathrm{Si}, \mathrm{Ni}, \mathrm{Cr}$, $\mathrm{V}$ dan lain sebagainya yang tersusun dalam prosentase yang sangat kecil. Dan unsurunsur tersebut akan berpengaruh terhadap mutu dari baja tersebut.

Pada baja karbon rendah mempunyai kandungan karbon \% C $<0,3 \%$. Sifat kekerasannya relatif rendah, lunak dan keuletannya tinggi. Baja karbon rendah biasanya digunakan dalam bentuk pelat, profil, sekrap, ulir dan baut.

\section{Pengerasan Permukaan Baja (Steel Surface Hardening)}

Pengerasan permukaan dilakukan dengan 2 cara yaitu seluruh permukaan dikeraskan atau sebagian saja dari permukaan yang dikeraskan. Tujuan pengerasan permukaan secara umum adalah memperbaiki ketahanan aus dan ketahanan korosi. Pengerasan permukaan pada baja meliputi dua jenis yaitu Induction Hardening dan Thermo Chemical Treatment.

Prinsip kerja Induction Hardening adalah memanaskan permukaan baja hingga temperatur austenit yang sesuai dengan baja yang bersangkutan, kemudian disemprotkan pendingin sehingga permukaan menjadi keras.

Prinsip kerja dari Thermo Chemical Treatment adalah menambahkan unsur karbon ke dalam baja untuk mengeraskan bagian permukaan baja tersebut. Salah satu penerapan dari proses Thermo Chemical Treatment adalah carburising (pengarbonan).

Thermo Chemical Treatment dilakukan terhadap baja yang mempunyai kadar karbon di bawah 0,3\%. Kadar karbon ini tidak memungkinkan terjadinya fasa martensit yang keras.

\section{Carburising}

Pengarbonan(carburising) merupakan suatu proses penambahan kandungan karbon pada permukaan baja untuk mendapatkan sifat baja yang lebih keras pada permukaannya. Kondisi ini sangat diperlukan untuk komponen-komponen yang mensyaratkan tahan aus.

Pada pengarbonan padat, dipakai arang yang dicampur dengan 10\% - 20\% $\mathrm{Na}_{2} \mathrm{CO}_{3}$ $/ \mathrm{BaCO}_{3}$, baja dimasukan kedalam campuran ini, ditempelkan pada suatu wadah dan ditutup rapat kemudian dipanaskan. Dengan demikian permukaan baja akan mempunyai kadar karbon yang lebih tinggi.

Kandungan karbon akan bervariasi dalam arah menuju inti. Pada permukaan kandungan karbon tinggi, dan akan berkurang dalam arah menuju inti. Konsekuensinya struktur mikro akan berubah pula dari permukaan menuju inti.

\section{Quenching}

Quench (celup cepat) adalah salah satu perlakuan panas dengan laju pendinginan cepat yang dilakukan dalam suatu media pendingin misal air atau oli. Untuk memperoleh sifat mekanik yang lebih keras. Untuk baja karbon rendah dan baja karbon sedang lazim dilakukan pencelupan dengan air.

Untuk baja karbon tinggi dan baja paduan biasanya digunakan minyak sebagai media pencelupan, pendinginannya tidak secepat air. Tersedia berbagai jenis minyak, seperti minyak mineral dengan kecepatan pendinginan yang berlainan sehingga dapat diperoleh baja dengan berbagai tingkat 
kekerasan. Untuk pendinginan yang cepat dapat digunakan air garam atau air yang disemprotkan. Beberapa jenis logam dapat dikeraskan melalui pendinginan udara terlalu lambat. Benda yang agak besar biasanya dicelup dalam minyak. Suhu media celup harus merata agar dapat dicapai pendinginan yang merata pula. Media pendinginan yang digunakan dalam produksi harus dilengkapi dengan perlengkapan pendinginan.

\section{METODOLOGI PENELITIAN}

Metode yang dipergunakan dalam penelitian ini merupakan metode eksperimen, setelah melakukan survey. Secara skematis alur penelitian seperti terlihat pada gambar 1 .

\section{HASIL DAN PEMBAHASAN Hasil Pengujian Kekerasan}

Pengujian kekerasan dilakukan dengan menggunakan metode kekerasan Vickers, dengan pembebanan 1000 gf untuk setiap material. Pengujian kekerasan juga dilakukan terhadap material dasar untuk melihat perbandingan kekerasan antara material dasar dengan material pengarbonan.

Pelaksanaannya dimulai dari titik pinggir material pengarbonan menuju inti material tersebut dan lokasi titik uji kekerasan dapat dilihat pada gambar 3. Sedangkan untuk material dasar sebagaimana terlihat pada gambar 2. Hasil pengujian kekerasan dapat dilihat pada tabel 1 sampai dengan tabel 5 .

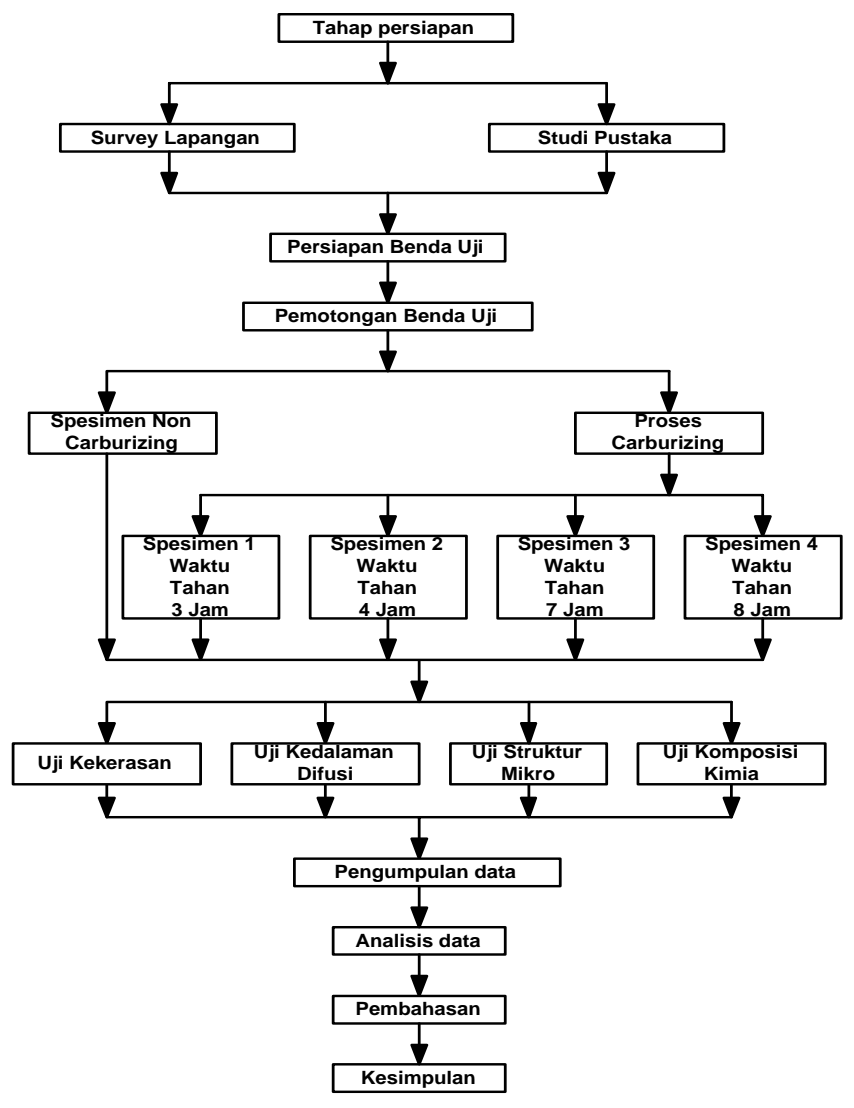

Gambar 1. Diagram alir penelitian 
Tabel 1 Harga kekerasan material dasar

\begin{tabular}{|c|c|c|c|c|c|}
\hline No & $\begin{array}{c}\text { Jarak dari tepi } \\
\text { (mm) }\end{array}$ & D1 & D2 & $\begin{array}{l}\text { D rata- } \\
\text { rata }\end{array}$ & $\begin{array}{c}\text { HVN } \\
\left(\mathbf{k g} / \mathbf{m m}^{2}\right)\end{array}$ \\
\hline 1 & 0.2 & 92.4 & 92.6 & 92.5 & 216.8 \\
\hline 2 & 0.5 & 93.1 & 92.9 & 93 & 214.3 \\
\hline 3 & 0.8 & 95.7 & 96.4 & 96.05 & 200.9 \\
\hline 4 & 1.5 & 96.2 & 96.6 & 96.4 & 199.5 \\
\hline 5 & 3 & 97.2 & 97 & 97.1 & 196.6 \\
\hline
\end{tabular}

Tabel 2. Harga kekerasan material pengarbonan dengan waktu tahan 3 jam

\begin{tabular}{|c|c|c|c|c|c|}
\hline No & $\begin{array}{c}\text { Jarak dari tepi } \\
(\mathbf{m m})\end{array}$ & D1 & D2 & D rata-rata & HVN (kg/mm²) \\
\hline 1 & 0.2 & 49.3 & 51.1 & 50.2 & 735.7 \\
\hline 2 & 0.5 & 57.8 & 58.3 & 58.05 & 550.3 \\
\hline 3 & 0.8 & 60.3 & 60.8 & 60.55 & 505.7 \\
\hline 4 & 1.5 & 63.2 & 63.4 & 63.3 & 462.8 \\
\hline 5 & 3 & 64.8 & 64.9 & 64.85 & 440.9 \\
\hline
\end{tabular}

Tabel 3. Harga kekerasan material pengarbonan dengan waktu tahan 4 jam

\begin{tabular}{|c|c|c|c|c|c|}
\hline No & $\begin{array}{c}\text { Jarak dari tepi } \\
\text { (mm) }\end{array}$ & D1 & D2 & $\begin{array}{c}\text { D rata- } \\
\text { rata }\end{array}$ & $\begin{array}{c}\mathbf{H V N} \\
\left(\mathbf{k g} / \mathbf{m m}^{\mathbf{2}}\right)\end{array}$ \\
\hline 1 & 0.2 & 49.2 & 49.4 & 49.3 & 762.9 \\
\hline 2 & 0.5 & 54,1 & 54,3 & 54,2 & 631 \\
\hline 3 & 0.8 & 59,5 & 59,9 & 59,7 & 520 \\
\hline 4 & 1.5 & 61,7 & 61,3 & 61,5 & 490,2 \\
\hline 5 & 3 & 63,2 & 64,9 & 64,85 & 462,8 \\
\hline
\end{tabular}

Tabel 4. Harga kekerasan material pengarbonan dengan waktu tahan 7 jam

\begin{tabular}{|c|c|c|c|c|c|}
\hline No & $\begin{array}{c}\text { Jarak dari tepi } \\
(\mathbf{m m})\end{array}$ & D1 & D2 & D rata-rata & $\begin{array}{c}\text { HVN } \\
\text { (kg/mm2) }\end{array}$ \\
\hline 1 & 0.2 & 48.6 & 48.8 & 48.7 & 781.9 \\
\hline 2 & 0.5 & 51 & 51.8 & 51.4 & 702.1 \\
\hline 3 & 0.8 & 57.9 & 58.3 & 58.1 & 549.3 \\
\hline 4 & 1.5 & 59 & 58.8 & 58.9 & 534.4 \\
\hline 5 & 3 & 62.2 & 62.3 & 62.25 & 478.4 \\
\hline
\end{tabular}

Tabel 5. Harga kekerasan material pengarbonan dengan waktu tahan 8 jam

\begin{tabular}{|c|c|c|c|c|c|}
\hline No & $\begin{array}{c}\text { Jarak dari tepi } \\
(\mathbf{m m})\end{array}$ & D1 & D2 & D rata-rata & HVN $\mathbf{( k g / \mathbf { m m } ^ { 2 } )}$ \\
\hline 1 & 0.2 & 48 & 48.2 & 48.1 & 801.5 \\
\hline 2 & 0.5 & 50.2 & 51.4 & 50.3 & 732 \\
\hline 3 & 0.8 & 54.6 & 54.7 & 54.65 & 620.8 \\
\hline 4 & 1.5 & 57.6 & 58 & 57.8 & 551.1 \\
\hline 5 & 3 & 62.1 & 62.3 & 62.2 & 479.3 \\
\hline
\end{tabular}




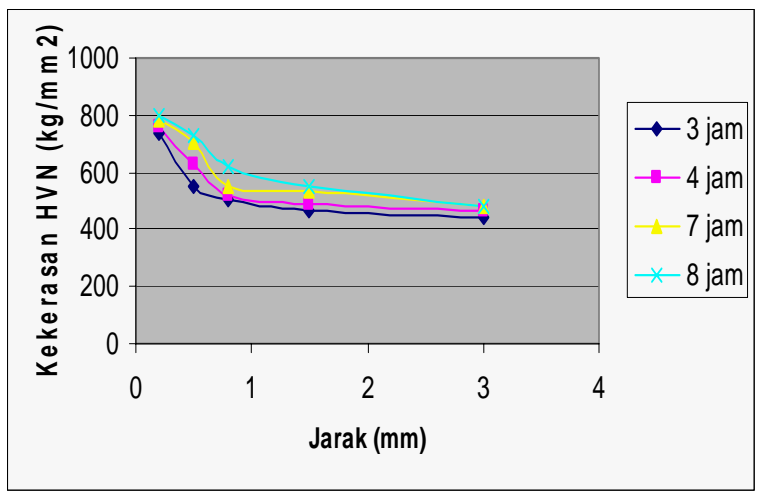

Gambar 2. Grafik hasil pengujian kekerasan material pengarbonan

Tabel 6. Kedalam Difusi

\begin{tabular}{|c|c|c|}
\hline No & $\begin{array}{c}\text { Waktu penahanan } \\
\text { (jam) }\end{array}$ & $\begin{array}{c}\text { Kedalaman difusi } \\
\text { (mm) }\end{array}$ \\
\hline 1 & 3 & 0.1155 \\
\hline 2 & 4 & 0.1617 \\
\hline 3 & 7 & 0.3773 \\
\hline 4 & 8 & 0.4774 \\
\hline
\end{tabular}

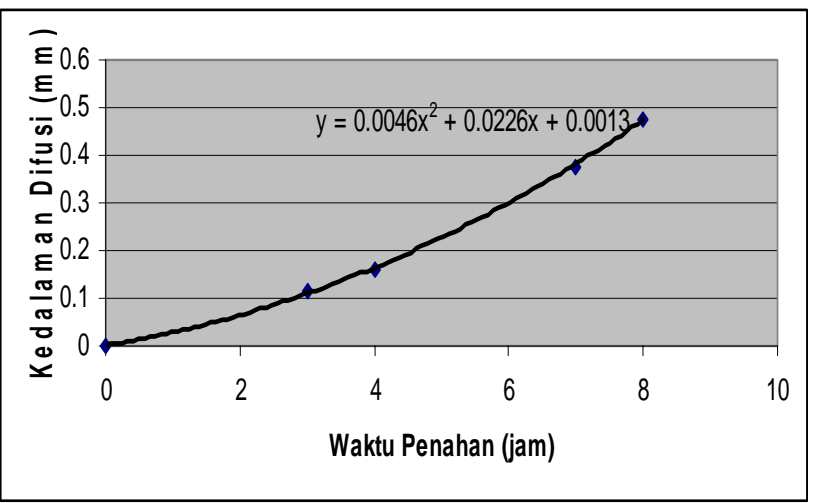

Gambar 3. Grafik hasil pengujian kedalaman difusi material pengarbonan

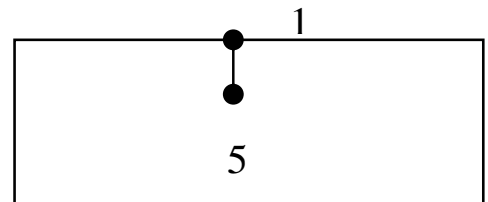

Gambar 4. Skema letak pengujian kekerasan material dasar

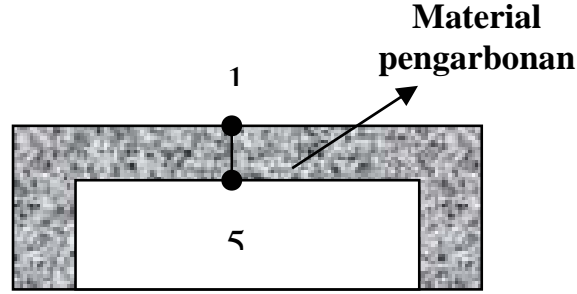

Gambar 5. Skema letak titik pengujian kekerasan material pengarbonan 


\section{Hasil Pengujian Kedalaman Difusi}

Hasil pengukuran kedalaman difusi atom karbon matrial pengarbonan dengan variasi waktu penahan 3 jam, 4 jam, 7 jam, 8jam, dapat dilihat pada Tabel 6 .

\section{Hasil Pengujian Komposisi Kimia}

Pengujian komposisi kimia dilakukan dengan mesin spektrum komposisi kimia universal yang memberikan hasil pembacaan kadar komposisi kimia benda uji. Dalam pengujian ini dilakukan 3 kali penembakan yang nantinya dapat diambil nilai rata-rata.

Tabel 7. Komposisi kimia

\begin{tabular}{|c|c|c|c|c|}
\hline \multirow{2}{*}{ Unsur paduan } & \multicolumn{4}{|c|}{ Komposisi rata-rata (\%) } \\
\hline & $\begin{array}{c}\text { Waktu tahan } \\
3 \text { jam }\end{array}$ & $\begin{array}{c}\text { Waktu tahan } \\
4 \text { jam }\end{array}$ & $\begin{array}{l}\text { Waktu tahan } \\
7 \text { jam }\end{array}$ & $\begin{array}{l}\text { Waktu Tahan } \\
8 \text { jam }\end{array}$ \\
\hline Ferro $(\mathrm{Fe})$ & 95.81 & 95.68 & 95.53 & 95.19 \\
\hline Silikon $(\mathrm{Si})$ & 0.25 & 0.25 & 0.252 & 0.263 \\
\hline Vanadium (V) & $<0.001$ & $<0.001$ & $<0.001$ & $<0.001$ \\
\hline Cobalt (Co) & 0.013 & 0.013 & 0.013 & 0.013 \\
\hline Carbon ( C ) & 0.259 & 0.352 & 0.505 & 0.808 \\
\hline Cuprum $(\mathrm{Cu})$ & 0.184 & 0.188 & 0.187 & 0.19 \\
\hline Titanium (Ti) & $<0.000$ & $<0.000$ & $<0.000$ & $<0.000$ \\
\hline Niobium (Nb) & 0.005 & 0.005 & 0.005 & 0.006 \\
\hline Mangaan (Mn) & 0.421 & 0.425 & 0.429 & 0.43 \\
\hline Nikel (Ni) & 1.669 & 1.694 & 1.684 & 1.694 \\
\hline Aluminium (Al) & 0.014 & 0.013 & 0.014 & 0.015 \\
\hline Phospor (P) & 0.011 & 0.014 & 0.014 & 0.013 \\
\hline Chrom (Cr) & 1.295 & 1.297 & 1.295 & 1.304 \\
\hline Boron (B) & $<0.000$ & $<0.000$ & $<0.000$ & $<0.000$ \\
\hline Sulfur (S) & 0.025 & 0.025 & 0.025 & 0.029 \\
\hline Molibdenium (Mo) & 0.009 & 0.009 & 0.009 & 0.01 \\
\hline Wolfram (W) & 0.037 & 0.038 & 0.037 & 0.035 \\
\hline
\end{tabular}

\section{Pengujian Struktur Mikro}

Dari hasil foto struktur mikro material pengarbonan seperti terlihat pada gambar 6 . sampai gambar 14. dapat diamati bahwa pada bagian permukaan material pengarbonan sesuai dengan variasi waktu tahan masing-masing material tersusun atas fasa martensit dan austenit sisa. Dari hasil foto struktur mikro juga dapat dilihat adanya difusi karbon yang berbeda sesuai variasi waktu tahan masing-masing material.

\section{Pengujian Kekerasan Mikro}

Pengujian kekerasan yang dilakukan pada material pengarbonan menghasilkan distri-busi kekerasan yang berbeda dari bagian permukaan menuju inti. Hasil pengujian kekerasan mikro material pengarbonan dengan variasi waktu penahanan 3 jam ; 4 jam ; 7 jam ; 8 jam dapat dilihat pada tabel 2. sampai dengan table 5. Perbedaan tingkat kekerasan tersebut dipengaruhi oleh variasi waktu tahan yang digunakan selama proses pengarbonan, sehingga atom $\mathrm{C}$ yang terbentuk makin banyak yang akan mempengaruhi peningkatan kekerasan. Sebagaimana tampak pada gambar 14 . harga material pengarbonan semakin kecil searah menuju inti untuk masing-masing 
waktu tahan. Hal ini disebabkan oleh kadar karbon dalam arah menuju inti juga semakin berkurang. Namun pada jarak yang sama dari permukaan harga kekerasan berbeda untuk masing-masing waktu penahanan dan cenderung menjadi lebih keras untuk waktu penahanan yang semakin lama, yang berarti kadar karbon semakin meningkat. Jadi semakin lama waktu penahanan maka harga kekerasan pada jarak tertentu dari permukaan akan semakin keras, akibatnya semakin banyak terbentuk fasa martensit pada bagian prmukaan material pengarbonan.

\section{Pengujian Kedalaman Difusi}

Hasil pengukuran kedalaman difusi atom karbon kedalam material terlihat pada table 6. dan hasil pengukuran tersebut dinyatakan dalam bentuk diagram kedalaman difusi dan dari kurva yang terbentuk akan didapat persamaan kurva, seperti terlihat pada gambar 15.

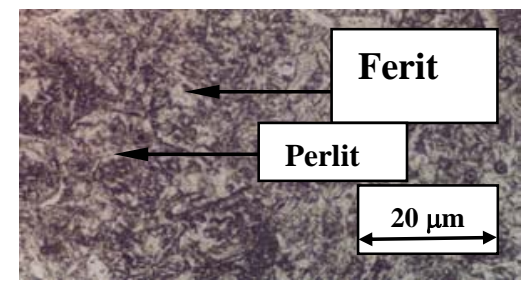

\section{Gambar 6. Struktur mikro material dasar}

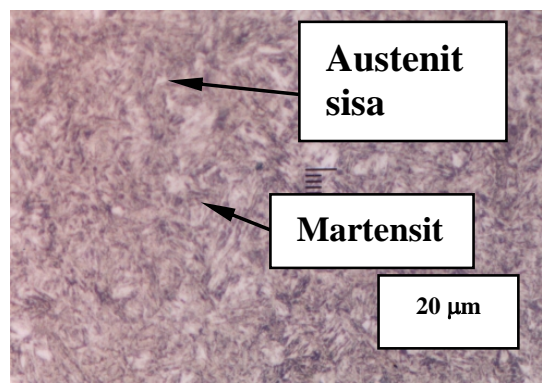

Gambar 8. Foto Struktur Mikro Material Pengarbonan Waktu Tahan 3 Jam
Dari gambar tersebut tampak bahwa semakin lama waktu penahanan dalam proses pengarbonan maka akan semakin meningkatkan kedalaman difusi. Hal ini disebabkan oleh difusi atom $\mathrm{C}$ yang makin jauh kedalam material pengarbonan.

\section{Pengujian Komposisi Kimia}

Hasil pengujian komposisi kimia material pengarbonan dengan variasi waktu tahan 3 jam; 4 jam; 7 jam; 8 jam menunjukkan bahwa kandungan unsur karbonnya semakin meningkat. Peningkatan unsur karbon tersebut dipengaruhi oleh makin lamanya waktu tahan yang digunakan selama proses pengarbonan. Dimana temperature media karburisasi terurai menjadi CO yang selanjutnya terurai menjadi karbon aktif,yang dapat berdifusi masuk kedalam material, sehingga menaikkan kadar karbon dalam material. Adapun hasil pengujian komposisi kimia dapat dilihat pada tabel 7 .

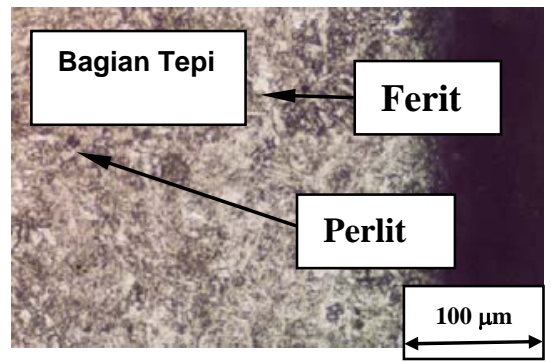

Gambar 7. Foto struktur mikro material dasar bagian tepi

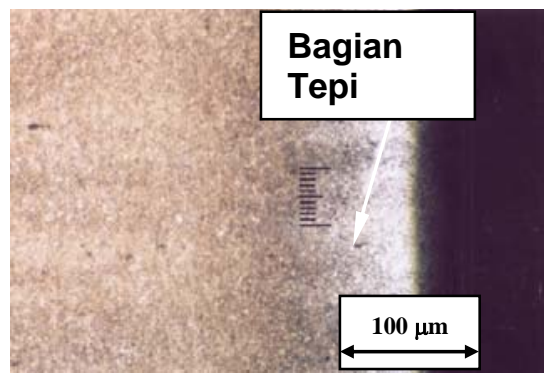

Gambar 9. Foto struktur mikro kedalaman difusi material pengarbonan waktu tahan 3 jam 


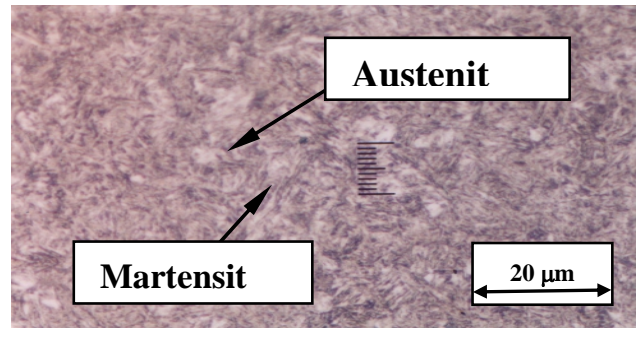

Gambar 10. struktur mikro material pengarbonan waktu tahan 4 jam

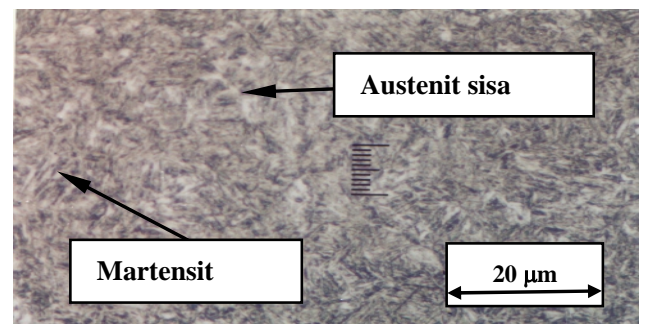

Gambar 12. Struktur mikro kedalaman difusi material pengarbonan waktu tahan 7 jam

\section{KESIMPULAN}

Setelah melakukan beberapa pengujian yang meliputi pengujian struktur mikro, pengujian kekerasan, pengujian kedalaman difusi, dan pengujian komposisi kimia pada material pengarbonan maka diambil kesimpulan sebagai berikut ini.

Hasil pengamatan foto struktur mikro pada bagian permukaan menunjukkan fasa martensit, semakin banyak fasa martensit

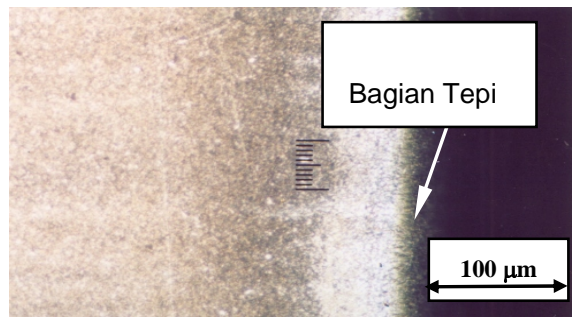

Gambar 11. Struktur mikro kedalaman difusi material pengarbonan waktu tahan 4 jam

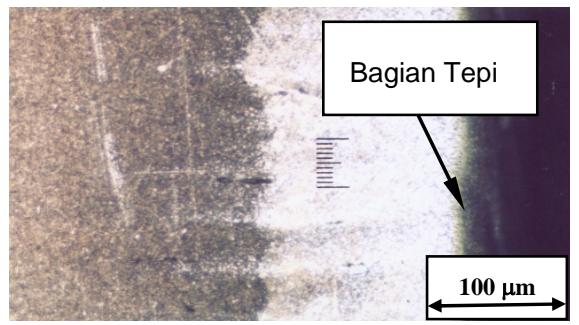

\begin{abstract}
Gambar 13. Struktur mikro kedalaman difusi material pengarbonan waktu tahan 8 jam
\end{abstract}

yang terbentuk menyebabkan tingkat kekerasan semakin tinggi searah dengan meningkatnya variasi waktu tahan. Hasil pengujian kedalaman difusi dan komposisi kimia menunjukkan semakin dalam difusi karbon dan meningkatnya kadarkarbon dipengaruhi oleh variasi waktu tahan. Semakin lama waktu tahan , semakin lama difusi karbon dan semakin meningkatnya komposisi unsur karbon.

\section{DAFTAR PUSTAKA}

Supriyono, 2001.Pengaruh Waktu Pengarbonan terhadap Distribusi Kekerasan dan Kedalaman Difusi pada Proses Pengarbonan Padat, Media Mesin, Jurusan Teknik Mesin UMS,Surakarta

Surdia T.,Saito S.,2000.Pengetahuan Bahan Teknik, Pradnya Paramita, Jakarta.

Van Vlack L.H.,G.E., 1991. Ilmu dan Teknologi Bahan, alih bahasa Djapirie S., Erlangga,Jakarta. 